\title{
THE MOVEMENT OF SERVICES BETWEEN THE EUROPEAN UNION AND SWITZERLAND
}

\begin{abstract}
Inga Kawka*
Summary: The article highlights the barriers in the provision of services between Switzerland and the EU which result from the restrictions introduced by Switzerland as regards free movement of persons and the fact that the FMPA has not been adjusted to the developing acquis of the Union. The obstacles in question are part of a broader context marked by the necessity to modernise the system of EU-Swiss bilateral agreements. The obligation on the Swiss federal government to renegotiate the FMPA which stems from the 'against mass immigration' referendum held on 9 February 2014 presents an opportunity to introduce between Switzerland and the Union a model for their relations which would be more coherent, transparent, dynamic and easier to manage and whose basis could be a framework or an association agreement.
\end{abstract}

\section{Introduction}

The European Union (EU) and its 28 Member States are Switzerland's most important partners for trade in services. However, barriers to trade in goods within the EU and between the EU and Switzerland were dismantled much more quickly than barriers to trade in services. This is a consequence of the high level of political sensitivity to problems in many service sectors (eg social issues) and of the difficulty in identifying technical rules (standards) regarding services which can be mutually recognised, but also of the political and legal determinants of relations between the EU and Switzerland.

The relations between the European Union and Switzerland are governed by bilateral agreements. ${ }^{1}$ The free movement of services is subject to the Agreement on the Free Movement of Persons (FMPA), ${ }^{2}$ one of seven accords signed on 21 June 1999 between the European Union and Swit-

PhD, Associate Professor, Chair of Law and Administrative Sciences, Institute of Political Sciences, Pedagogical University of Krakow. This research was funded by the Polish National Science Centre on the basis of decision number DEC-2013/09/B/HS5/04116.

1 Laurent Goetschel, 'Switzerland and European Integration: Change Through Distance' (2003) 8 EFA Rev 313; Stephan Breitenmoser, 'Sectoral Agreements between the EC and Switzerland: Contents and Context' (2003) 40 CMLR 1137.

2 Agreement of 21 June 1999 between the European Community and its Member States, of the one part, and the Swiss Confederation, of the other, on the free movement of persons [2002] OJ L114/ 6. 
zerland (Bilaterals I) which came into force on 1 June 2002. In the FMPA, the right of free movement is complemented by the mutual recognition of professional qualifications, by the right to buy property, and by the coordination of social security systems. ${ }^{3}$ The aim of the Free Movement of Persons Agreement and its additional protocols is to lift restrictions on EU citizens wishing to live, work or carry out economic operations in Switzerland. The same rules apply to the citizens of EFTA states.

There exist two main problems with regard to the freedom of movement of services between EU states and Switzerland. Firstly, Switzerland does not automatically update its legislation to account for the most recent changes in secondary EU law. Secondly, as to the movement of persons who would like to provide services as employees or self-employed individuals, these persons are subject to immigration quotas.

\section{A dynamic EU acquis versus static bilateral accords between the EU and Switzerland in the area of services}

The basis for the freedoms of establishment and service provision in the EU is primary law, in particular Article $49 \mathrm{TFEU}$, the role of which is to ensure the freedom of choice as regards the place of establishment within EU territory by natural and legal persons, and Article 56 TFEU which prohibits restrictions on freedom to provide services within the EU. The Court of Justice has found both provisions to be directly effective, ${ }^{4}$ and their fundamental objective is to remove barriers for operators being nationals of one Member State who wish to establish, provide or use services in another Member State.

When it comes to economic operation as a service provider, the impact on the EU internal market is also exerted by sectoral directives serving to harmonise Member States' legislation in such areas as: telecommunications, postal services, energy, financial services (banking and insurance), medical services, electronic commerce, media services, road, maritime, rail and air transport as well as inland waterways. EU legislation focuses on sectors of particular importance for the growth of the European economy as well as those with most legal barriers in terms of movement of services and freedom of establishment as well as services that could cross the border themselves (without the service provider or service recipient). ${ }^{5}$ Additionally, some acts of secondary law are horizontal and embrace nu-

\footnotetext{
Chistine Kaddous, Diane Griesel, Libre circulation des personnes et des services (Helbing Lichtenhahn Verlag 2012) 845.

4 Case 48/75 Jean Noël Royer [1976] ECR 497, point 31; Case 2/74 Jean Reyners $v$ Belgian State [1974] ECR 631.

5 Bruno de Witte, 'Setting the Scene: How did Service Get to Bolkstein and Why?' 2007(3) Michell Working Paper Series 5.
} 
merous sectors, eg the Directive on the recognition of qualifications ${ }^{6}$ and the Service Directive, ${ }^{7}$ the goal of which is largely to facilitate the implementation of the principles stemming from the treaties.

The basic secondary law act of a horizontal nature in the domain of services is Directive 2006/123/EC on services in the internal market (Services Directive). The objective of the directive is the 'elimination of barriers to the development of service activities between Member States'. This is the legal act that is supposed to lead to changes on the European internal market and to eliminate barriers in the movement of services and the free establishment of service providers in other Member States present despite treaty provisions and the jurisprudence of EU courts. When it comes to the freedom of establishment, however, the directive mainly prohibits making it possible to take up or provide services dependent on any authorisation system, which may be introduced by way of exception only. The main sectors covered by the Services Directive are: services for enterprises, including those provided by free professionals (lawyers, architects, accountants, tax advisers, consulting agencies, communication and marketing agencies, patent agents, certification service providers, sports agents, artists' managers, job agencies, interpreters, veterinarians, surveyors, etc); construction services and craftsmanship; the retail sector; real estate; tourism (hotels, restaurants, cafés, travel agents, tourist guides, etc); private education.

The other legal act applicable horizontally to all kinds of services is Directive 2005/36/EC. It concerns the removal of specific barriers. The goal of the directive is the establishment of a system for mutual recognition of professional qualifications between the Member States so as to facilitate the removal of barriers in the free movement of persons and services within the internal market. The directive sets separate rules as regards the recognition of qualifications for cross-border and temporary service provision as well as establishment in another Member State. ${ }^{9}$

The realisation of the single European service market is currently one of the key interests of the EU legislator. In its acts related to the single market, the Commission has recognised initiatives aimed at removing legal and administrative barriers in the area of services as a lever for economic growth in Europe. Some of the initiatives announced have already been introduced and some are subject to ongoing legislative procedures or

\footnotetext{
6 Directive 2005/36/EC of the European Parliament and of the Council of 7 September 2005 on the recognition of professional qualifications [2005] OJ L255/22-142.

7 Directive 2006/123/EC of the European Parliament and of the Council of 12 December 2006 on services in the internal market [2006] OJ L376/36-68 (Services Directive).

8 Point 1 of the preamble of the Services Directive.

9 The Directive on the recognition of professional qualifications also includes within its scope the recognition of qualifications of workers.
} 
discussions, eg in the areas of: recognition of qualifications, ${ }^{10}$ retail trade services, ${ }^{11}$ recognition of the electronic signature, ${ }^{12}$ transport services, ${ }^{13}$ gambling, ${ }^{14}$ payment services,${ }^{15}$ telecommunications and broadband Internet access services, ${ }^{16}$ as well as banking services. ${ }^{17}$

Both freedoms of establishment and service provision, the implementation of which facilitates the creation of an EU single internal market, are only in a limited scope regulated in bilateral agreements between the EU and Switzerland, and the scope of Swiss-EU integration is much narrower than integration in the context of the EU internal market. First,

10 Directive 2013/55/EU of the European Parliament and of the Council of 20 November 2013 amending Directive 2005/36/EC on the recognition of professional qualifications and Regulation (EU) No 1024/2012 on administrative cooperation through the Internal Market Information System ('IMI Regulation') [2013] OJ L354/132-170.

11 Commission, 'Setting up a European Retail Action Plan' (Communication) COM(2013) 36 final.

12 Commission, 'Proposal for a regulation of the European Parliament and of the Council on electronic identification and trust services for electronic transactions in the internal market $\operatorname{COM}(2012) 238$ final.

13 Commission, 'The fourth railway package - completing the single European railway area to foster European competitiveness and growth' (Communication) COM(2013) 25 final.

14 Commission, 'Towards a comprehensive European framework for online gambling' (Communication) $\operatorname{COM}(2012) 596$ final.

15 Regulation (EU) No 248/2014 of the European Parliament and of the Council of 26 February 2014 amending Regulation (EU) No 260/2012 as regards the migration to Union-wide credit transfers and direct debits [2014] OJ L84/1-3; Green Paper 'Towards an integrated European market for card, internet and mobile payments' COM(2011) 941 final; Commission, 'Proposal for a regulation of the European Parliament and of the Council on information accompanying transfers of funds' $\operatorname{COM}(2013) 44$ final.

16 Commission, 'Proposal for a Regulation of the European Parliament and of the Council laying down measures concerning the European single market for electronic communications and to achieve a Connected Continent, and amending Directives 2002/20/EC, 2002/21/EC and 2002/22/EC and Regulations (EC) No 1211/2009 and (EU) No 531/2012 $\operatorname{COM}(2013) 627$ final.

17 Commission, 'Proposal for a Regulation of the European Parliament and of the Council establishing uniform rules and a uniform procedure for the resolution of credit institutions and certain investment firms in the framework of a Single Resolution Mechanism and a Single Bank Resolution Fund and amending Regulation (EU) No 1093/2010 of the European Parliament and of the Council COM(2013) 520 final; Regulation (EU) No 1022/2013 of the European Parliament and of the Council of 22 October 2013 amending Regulation (EU) No 1093/2010 establishing a European Supervisory Authority (European Banking Authority) as regards the conferral of specific tasks on the European Central Bank pursuant to Council Regulation (EU) No 1024/2013 [2013] OJ L287/5-14; Council Regulation (EU) No 1024/2013 of 15 October 2013 conferring specific tasks on the European Central Bank concerning policies relating to the prudential supervision of credit institutions [2013] OJ L287/ 63-89; Directive 2013/36/EU of the European Parliament and of the Council of 26 June 2013 on access to the activity of credit institutions and the prudential supervision of credit institutions and investment firms, amending Directive 2002/87/EC and repealing Directives 2006/48/EC and 2006/49/EC [2013] OJ L176/338-436; Regulation (EU) No $575 / 2013$ of the European Parliament and of the Council of 26 June 2013 on prudential requirements for credit institutions and investment firms and amending Regulation (EU) No 648/2012 [2013] OJ L176/1-337. 
there is no separate agreement concerning the free movement of services. Free provision of services is covered in the FMPA of 1999, an accord which only partially regulates trade in services between the EU and Switzerland. The right to freely provide services is granted 'for a period not exceeding 90 days' of actual work in a calendar year' (Article 5 FMPA) and covers persons providing services and their employees, irrespective of their nationality (Article 17 of Annex I FMPA). In order to ensure the implementation of that freedom, the FMPA prohibits the introduction of 'any restriction on the cross-frontier provision of services' and 'any restriction on the right of entry and residence' (Article 17(a-b) of Annex I FMPA). Pursuant to Article 22(3) of Annex I FMPA, the freedom of service provision does not concern the activities of temporary and interim employment agencies or financial services. Further, Article 5 FMPA is not applicable to activities involving, even on an occasional basis, the exercise of public authority. Bilateral agreements between the EU and Switzerland also cover some of the sectors, in particular air, rail and road transport. The bilateral agreements on media ${ }^{18}$ and scientific and technological cooperation ${ }^{19}$ and one related to government procurement ${ }^{20}$ concern services only indirectly.

The FMPA also regulates the free movement between the EU and Switzerland of natural persons who undertake economic activities as self-employed persons. Legal persons, in turn, are not covered by the FMPA, a major gap in comparison with EU internal market law. In the EU-Swiss context, legal persons can enjoy the freedom of establishment to a limited extent on the basis of agreements concerning individual sectors like insurance ${ }^{21}$ or air transport. ${ }^{22}$

Bilateral agreements between the EU and Switzerland are of a rather static nature. Most, like the FMPA, include in their annexes a list of legal acts to be implemented by Switzerland (pre-signature acquis/fixed acquis). ${ }^{23}$ This is the case although the basis for FMPA implementation

\footnotetext{
18 Agreement between the European Community and the Swiss Confederation in the audiovisual field, establishing the terms and conditions for the participation of the Swiss Confederation in the Community programmes MEDIA Plus and MEDIA Training [2007] OJ L303/11.

19 Agreement on scientific and technological cooperation between the European Community and the European Atomic Energy Community, of the one part, and the Swiss Confederation, of the other part [2007] OJ L189/26.

20 Agreement between the European Community and the Swiss Confederation on certain aspects of government procurement [2002] OJ L114/430.

${ }^{21}$ Agreement between the Swiss Confederation and the European Economic Community on direct insurance other than life insurance [1991] OJ L205/3.

${ }^{22}$ Agreement between the European Community and the Swiss Confederation on Air Transport [2002] OJ L114/73.

${ }^{23}$ Andrés Delgado Casteleiro, 'Relations Between European Union and Switzerland: A Laboratory for UE External Relations?' in Francesco Maiani, Roman Petrov and Ekaterina
} 
is the principle of equivalence between EU and Swiss laws. ${ }^{24}$ It is to be implemented in the context of joint committees composed of representatives of the Union and Switzerland. ${ }^{25}$ The FMPA provides for a notification and consultation mechanism related to changes in Swiss and EU law applicable to the area covered by the FMPA (Article 17 FMPA) and the possibility of amending Annexes II and III FMPA (Article 18 FMPA). The modifications may be made on the basis of decisions taken by the Joint Committee. In many cases, the diplomatic efforts by the parties to the FMPA made in the context of Joint Committees do not result in mutually acceptable solutions. Thereby, Switzerland is free to adopt bills implementing the EU acquis after the bilateral agreement was signed. ${ }^{26}$ Consequently, Switzerland can do some cherry-picking in certain areas of the EU acquis and does not automatically update its legislation to take into account the most recent changes in secondary EU law. ${ }^{27}$ This is exacerbated by the fact that the committees meet only rarely (once or twice a year) and there is lack of transparency in the negotiations on updates of EU-Swiss bilateral agreements, while information exchange between EU administration and committees as well as between the committees themselves is not sufficiently intensive. As a result of this fragmented institutional framework, the FMPA is behind in updating. ${ }^{28}$

Considering some EU directives related to the exercise of internal market freedoms of fundamental importance for the development of the EU internal market, the Services Directive, ${ }^{29}$ the Directive concerning free movement of EU citizens ${ }^{30}$ and the Directive on the recognition of

\footnotetext{
Mouliarova (eds), European Integration Without EU Membership Models, Experiences, Perspectives (2009) MWP Working Papers 11/2009, 107 <http://cadmus.eui.eu/bitstream/ handle/1814/11294/MWP_2009_10.pdf?sequence=1> accessed 10 May 2014.

24 Carl-Alex Ridoré, 'L'effet horizontal de la libre circulation des personnes en droit communautaire: Ses fondements, son régime et sa transposition à l'Accord Suisse-CE sur la libre circulation des personnes (ALCP)' (Berne 2012) 155.

25 Adam Lazowski, 'Enhanced Multilateralism and Enhanced Bilateralism: Integration Without Membership in the European Union (2008) 45 CMLR 1433, 1449.

26 David Buchan, 'Outsiders on the Inside: Swiss and Norwegian Lessons for the UK' (Centre for European Reform, September 2012) <http://www.cer.org.uk/sites/default/files/ publications/attachments/pdf/2012/buchan_swiss_norway_11oct12-6427.pdf > accessed 20 May 2014.

27 Adam Łazowski, 'Switzerland' in Steven Blockmans and Adam Lazowski (eds), The European Union and Its Neighbours (TMC Asser Press 2006) 157.

28 European Parliament, Directorate General For Internal Policies, Policy Department A: Economic and Scientific Policy, Internal Market and Consumer Protection (Briefing Paper, January 2010) <http://www.europarl.europa.eu/document/activities/cont/201003/2010 0315ATT70636/20100315ATT70636EN.pdf>, accessed 10 May 2014; Marc Maresceau, EU-Switzerland: Quo Vadis? (2011) 39 Georgia Journal of International and Comparative Law 727.

29 Directive 2006/123/EC of the European Parliament and of the Council of 12 December 2006 on services in the internal market [2006] OJ L376/36.

30 Directive 2004/38/EC of the European Parliament and of the Council of 29 April 2004
} 
qualifications, ${ }^{31}$ Switzerland has pledged to implement just one of these legal acts by a Joint Committee decision changing Annex III to the FMPA titled 'Mutual recognition of professional qualifications'. ${ }^{32}$ The Services Directive and Directive 2004/38/EC concern subjects covered by Annex I, for which the Joint Committee is not competent. Given the additional fact that the bilateral agreements pertain to services only selectively, Switzerland will not be willing to implement the Services Directive. Directive 2004/38, which to a large extent codifies CJEU jurisprudence concerning free movement of persons and includes earlier secondary EU law in that area, was not made part of the FMPA. The reason for this is the fact that the said Directive is to a large degree founded on the notion of EU citizenship which is not reflected in the bilateral agreements. Incidentally, the notion of EU citizenship does not feature in the EEA Agreement either, and still Directive 2004/38 was made part of it by an EEA Joint Committee decision. ${ }^{33}$ Swiss law also does not provide for legislation or jurisprudencebased mechanisms which would ensure the euro-compatibility of Swiss law amended by way of autonomous implementation, ie without international obligations and which would in that way ensure the homogeneity of the European legal area. ${ }^{34}$

Differences in integration can be seen in the example of legal services. The Service Directive regulates the simplification of administrative procedures, eg by creating points of single contact which make available information on procedures related to conducting economic operations in the territory of the host state and facilitating their possible delivery online. The procedures related to the entry onto the list of foreign advocates should be described on the website of the Member States' points of single contact and conducted electronically. The Service Directive also includes an instruction related to legal professions to do away with 'all total prohibitions on commercial communications by the regulated professions' (Article 24) and lists requirements to be met by the rules in the Member

on the right of citizens of the Union and their family members to move and reside freely within the territory of the Member States amending Regulation (EEC) No 1612/68 and repealing Directives 64/221/EEC, 68/360/EEC, 72/194/EEC, 73/148/EEC, 75/34/EEC, 75/35/EEC, 90/364/EEC, 90/365/EEC and 93/96/EEC [2004] OJ L158/77.

31 Directive 2005/36/EC of the European Parliament and of the Council of 7 September 2005 on the recognition of professional qualifications [2005] OJ L255/22.

32 Decision No 2/2011 of the EU-Swiss Joint Committee Established by Article 14 of the Agreement Between the European Community and its Member States, of the One Part, and the Swiss Confederation, of the Other, on the Free Movement of Persons of 30 September 2011 replacing Annex III (Mutual recognition of professional qualifications) thereto [2011] OJ L277/20.

33 Decision of the EEA Joint Committee No 158/2007 of 7 December 2007 amending Annex V (Free movement of workers) and Annex VIII (Right of establishment) to the EEA Agreement [2008] OJ L124/20.

34 Francesco Maiani, 'Lost in Translation: Euro-compatibility, Legal Security, and the Autonomous Implementation of EU Law in Switzerland' (2013) 1 European Law Reporter 33. 
States governing commercial communications by the regulated professions. The Service Directive also concerns the delivery of legal services through multidisciplinary practices (Article 25) and questions of professional liability insurance and guarantees. The lack of implementation into Swiss law of Directive 2004/38 also caused a discrepancy between the free movement and residence rights of Swiss and EU/EEA nationals. ${ }^{35}$

Furthermore, Switzerland does not automatically comply with the case law of the CJEU concerning the freedoms of the internal market delivered after the FMPA conclusion. Article 16(2), second sentence of the FMPA, establishes a mechanism for notifying this case law to Switzerland. It is the Joint Committee's remit to define specific consequences that CJEU case law may have for the operation of the FMPA. ${ }^{36}$ An example of difficulties stemming from this is CJEU judgements on notaries which have not been taken into account in Swiss law.

The EU-Switzerland bilateral agreements also leave out the nonlegal ways of integrating the legal systems of the Member States which considerably modernise the classic Community method and supplement the command and control mechanism of implementing EU law into domestic systems. Attempts at overcoming difficulties in the creation of the European single market consist of actions which are called new governance, good governance or better governance in primary sources ${ }^{37}$ and in documents issued by the Commission. ${ }^{38}$

\footnotetext{
35 Matthew Jay, 'Homogeneity, the Free Movement of Persons and Integration without Membership: Mission Impossible?' (2012) 8 CYELP 77; Andreas Zünd, 'The Implementation of the Free Movement of Persons Agreement between Switzerland and the EU' (2003) 1 European Law Reporter 23.

36 Véronique Boillet, L'interdiction de discrimination en raison de la nationalité au sens de l'Accord sur la libre circulation des personnes (Helbing Lichtenhahn 2010) 73.

37 Patrycja Dąbrowska 'Koncepcja "nowego rządzenia" w prawie Unii Europejskiej a Konstytucja dla Europy' in Sławomir Dudzik (ed), Konstytucja dla Europy. Przyszły fundament Unii Europejskiej (Kraków 2005) 191; Rosa Comella 'New Governance Fatigue? Administration and Democracy in the European Union' (2006) 6 Jean Monnet Working Paper 9; Jose Candela Castillo, La bonne gouvernance comprise comme intégration des princicpes de légitimité efficacité et justice (2005) 2 Revue du droit de 1'Union européenne 243; Grainne de Búrca and Joanne Scott 'Introduction' in Grainne de Búrca and Joanne Scott (eds), Law and New Governance in the EU and the US (Hart Publishing 2006) 3; Hubert Izdebski, 'Od administracji publicznej do public governance' (2007) 1 Zarzadzanie publiczne 7-20; Daniela Obradovic and Jose M Alonso Vizcaino 'Good Governance Requirements Concerning the Participation of Interest Groups in EU Consultations' (2006) 43 CMLR 1049, 1085.

38 Commission, 'Single Market Act. Twelve levers to boost growth and strengthen confidence "Working together to create new growth"' (Communication) $\operatorname{COM}(2011) 206$ final; Commission, 'Single Market Act II Together for new growth' (Communication) COM(2012) 573 final; Commission, 'Better governance for the single market' (Communication) $\operatorname{COM}(2012) 259$ final; Commission, 'Report on a single market for growth and jobs: an analysis of progress made and remaining obstacles in the Member States - Contribution to the Annual Growth Survey 2014' COM(2013) 785 final.
} 
New governance leads to the transformation of the traditional Community method. Its basic feature is making binding legal acts directly applicable in domestic legislation and prevailing over the legislation of the Member States; by means of commands and bans directed at the Member States, such acts aim to approximate or consolidate their laws. One example of transforming the traditional Community method is the changes made since 2002 as part of the better/smart law-making programme. They include the simplification ${ }^{39}$ and improvement of the regulatory environment, eg thanks to the performance of regulatory impact assessments. ${ }^{40}$ At the same time, new governance consists of activities which supplement solutions provided for by such binding legal acts. These actions are or are not normative in nature, but use the command and control mechanism to a lesser degree. ${ }^{41}$ As noted by Vassilis Hatzopoulos, new governance is supposed to promote 'diversity, provisionality, policy learning, transparency, stakeholder participation, evaluation and review'. ${ }^{42}$

The Single Market Act suggests that the process of implementing the European internal market, also in terms of services, must be modernised, which is supposed to consist, inter alia, of better dialogue with civil society and close partnership with the various market participants. ${ }^{43}$ The notion of better governance was developed in the document called 'Making the Single Market Deliver: Annual Governance Check-up 2011'. There, the Commission enumerates all the stages of the governance cycle: monitoring of the correct and timely implementation of EU law by the Member States, informing EU citizens about their rights, simplification and acceleration of administrative procedures, strengthening of cooperation between competent administrative authorities of the Member States, solving issues which result from infringements of entitlements stemming from EU law, appraisal of the situation, adopting new regulations, or repealing or simplifying existing ones. One example of simplifying ways EU citizens can exercise their internal market rights is the SOLVIT network (informal networks of administrative bodies supposed to assist individuals in exercising their rights stemming from the EU acquis). To accomplish the single market of services, the structural method is also used (apart from the integration of the legal systems of the Members States which results from their top-bottom unification or harmonisation). EU funds are available to co-finance, for instance, projects serving to improve the

\footnotetext{
39 Commission Working Document, 'Third progress report on the strategy for simplifying the regulatory environment' $\mathrm{COM}(2009) 17$ final.

40 Commission, 'Smart regulation in the European Union' (Communication) $\operatorname{COM}(2010)$ 543 final; Commission, 'EU regulatory fitness' (Communication) COM(2012) 746 final.

41 de Búrca and Scott (n 37) 2.

42 Vassilis Hatzopoulos, Regulating Services in the European Union (OUP 2012) 430.

43 Commission, 'Single Market Act' (n 38) 22, 23.
} 
institutional capacity of economic administrations of the Member States and focus on the development of services provided in the general economic interest. Binding legal acts of EU law concerning services include legal norms which do not set commands or bans but some mechanisms aimed at inducing the Member States to adopt best solutions. Examples of such hybrid legal acts are the Services Directive and the Directive on the recognition of professional qualifications which establish a system of mutual evaluation of domestic regulations performed by the Member States and the European Commission. Such methods effectively complement the traditional ways of furthering the single European market but do not apply to Switzerland. For instance, Switzerland does not use instruments that improve administrative cooperation, eg the IMI system, and does not participate in SOLVIT.

\section{Immigration quotas}

The FMPA provides for the gradual introduction of the free movement of persons between Switzerland and the EU. The free movement of persons from the old 15 Member States, Cyprus and Malta has been ensured since 1 June 2007. As a result of the EU enlargement of 1 May 2004, the agreement was supplemented by an additional protocol containing provisions for the progressive introduction of the free movement of persons also in the case of the ten new EU Member States. ${ }^{44}$ The protocol came into force on 1 April 2006. In a referendum on 8 February 2009, the Swiss electorate approved the renewal of the Free Movement of Persons Agreement after 2009 and Protocol II on extending the Agreement to Romania and Bulgaria. ${ }^{45}$ However, the citizens of Bulgaria and Romania will remain subject to restrictions until 31 May 2016. ${ }^{46}$

The citizens of the EU-8 were granted unrestricted free movement rights on 1 May 2011, yet the first restrictions were imposed under Ar-

\footnotetext{
44 Protocol to the Agreement between the European Community and its Member States, of the one part, and the Swiss Confederation, of the other, on the free movement of persons regarding the participation, as contracting parties, of the Czech Republic, the Republic of Estonia, the Republic of Cyprus, the Republic of Latvia, the Republic of Lithuania, the Republic of Hungary, the Republic of Malta, the Republic of Poland, the Republic of Slovenia and the Slovak Republic pursuant to their accession to the European Union on 26 October 2004 [2006] OJ L89/30.

45 Protocol to the Agreement between the European Community and its Member States, of the one part, and the Swiss Confederation, of the other, on the free movement of persons, regarding the participation, as contracting parties of the Republic of Bulgaria and Romania pursuant to their accession to the European Union [2009] OJ L124/53. The protocol came into force on 1 June 2009.

46 Decision of the Swiss Federal Council of 28 May 2014, Press Release, <www.bfm.admin. $\mathrm{ch} /$ content/bfm/fr/home/dokumentation/medienmitteilungen/2014/ref_2014-05-282. html> accessed 30 May 2014.
} 
ticle 10(4) $\mathrm{FMPA}^{47}$ as early as 18 April 2012.48 In April 2013, the operation of the protective clause with regard to the EU-8 was prolonged for one more year and its application was expanded to cover the EU-17. As the immigration quotas could not, under the Swiss interpretation of the FMPA, be retained any further, the safeguard clause ceased to apply on 30 April 2014 for the EU-8 and on 31 May 2014 for the EU-17. ${ }^{49}$ The referendum held in Switzerland on 9 February 2014, in which the majority (50.3\%) of the Swiss voted against mass immigration, puts into question the free movement of persons between the EU and Switzerland. As a result of this referendum, Article 121a (immigration management) was added to the Swiss Federal Constitution ${ }^{50}$ stating that the number of residence permits for foreign nationals in Switzerland was restricted by caps and annual quotas. According to this new article of the Swiss Federal Constitution, the ceilings and annual quotas for foreign nationals undertaking economic activity may be defined depending on the global economic interest of Switzerland and in accordance with the country preference rule; they also include residents of border regions. The criteria

\footnotetext{
47 Article 10(4) FMPA provides that: 'notwithstanding the provisions of paragraph 3, the Contracting Parties have agreed on the following arrangements: if, after five years and up to 12 years after the entry into force of the Agreement, the number of new residence permits of either of the categories referred to in paragraph 1 issued to employed and self-employed persons of the European Community in a given year exceeds the average for the three preceding years by more than $10 \%$, Switzerland may, for the following year, unilaterally limit the number of new residence permits of that category for employed and self-employed persons of the European Community to the average of the three preceding years plus 5\%. The following year, the number may be limited to the same level. Notwithstanding the provisions of the previous subparagraph, the number of new residence permits issued to employed and self-employed persons of the European Community may not be limited to fewer than 15000 per year valid for a period equal to, or exceeding, one year and 115500 per year valid for more than four months and less than one year'.

48 According to the Council, the introduction of immigration quotas for the EU-8 was 'discriminatory and clearly in breach of the Agreement, and [the Council] strongly urges Switzerland to reverse its decision and to respect the agreed provisions'. Council conclusions on EU relations with EFTA countries $3213^{\text {th }}$ Report, Transport, Telecommunications and Energy, Council meeting, Brussels, 20 December 2012, point 35.

49 Swiss Federal Council, 30 April 2014, Press Release <www.bfm.admin.ch/content/bfm/ fr/home/dokumentation/medienmitteilungen/2014/ref_2014-04-301.html> accessed 10 May 2014.

50 Article 121a Gestion de l'immigration. '1 La Suisse gère de manière autonome l'immigration des étrangers. 2 Le nombre des autorisations délivrées pour le séjour des étrangers en Suisse est limité par des plafonds et des contingents annuels. Les plafonds valent pour toutes les autorisations délivrées en vertu du droit des étrangers, domaine de l'asile inclus. Le droit au séjour durable, au regroupement familial et aux prestations sociales peut être limité. 3 Les plafonds et les contingents annuels pour les étrangers exerçant une activité lucrative doivent être fixés en fonction des intérêts économiques globaux de la Suisse et dans le respect du principe de la préférence nationale; ils doivent inclure les frontaliers. Les critères déterminants pour l'octroi d'autorisations de séjour sont en particulier la demande d'un employeur, la capacité d'intégration et une source de revenus suffisante et autonome. 4 Aucun traité international contraire au présent article ne sera conclu. 5 La loi règle les modalités', RS 101.
} 
taken into account when granting the permit include, in particular, an employer's application, the ability to integrate, as well as a sufficient, autonomous source of income. The limits are defined for all categories of foreign nationals, and also include asylum. The right of permanent residence, to family reunification and to social benefits may be restricted. These provisions stand in clear contradiction to the FMPA, which prohibits discrimination on grounds of nationality (Article 2 FMPA). ${ }^{51}$ The quota system will also be directly incompatible with the following FMPA provisions: 1) the standstill principle under which the parties to the agreement do not adopt any further restrictive measures vis-à-vis each other's nationals in the fields covered by the FMPA; 2 ) the right of residence and access to an economic activity (Article 4 FMPA); 3) the right of residence for persons not pursuing an economic activity (Article 6 FMPA); 4) the right of residence for family members, irrespective of their nationality (Article 7(d) FMPA).

Article 121a of the Swiss Federal Constitution also provides that no international treaty conflicting with the above provisions can be entered into and that the law regulates the modalities. The provisions of that article are therefore not directly effective as they require legal texts detailing them to be issued. Transitional provisions were laid down in Article 197(9) of the Swiss Federal Constitution. ${ }^{52}$ In accordance with those provisions, the international treaties contravening Article 121(a) of the Constitution must be renegotiated and adjusted within three years of the adoption of the said article. If the appropriate implementing statutes do not come into effect within three years of the adoption of Article 121a of the Constitution, the Federal Council shall issue the necessary, temporary implementing regulations by decree.

These regulations indicate that Article 121(a) of the Swiss Federal Constitution does not cause an immediate termination by Switzerland of international treaties contravening it. Thus, the FMPA and other international treaties remain in effect. Negotiations between the EU and Switzerland will be difficult in that EU-Swiss bilateral agreements (Bilateral I) are linked in legal terms by a so-called 'guillotine clause', stipulating that they can only take effect together: if one of the agreements were not to be prolonged or terminated, the other would also cease to have effect. ${ }^{53}$ But there are also some immediate consequences of the referendum. The

\footnotetext{
51 Boillet (n 36) 81ff.

52 Article 197, ch 92.9 'Disposition transitoire ad art 121a (Gestion de l'immigration). 1 Les traités internationaux contraires à l'art 121a doivent être renégociés et adaptés dans un délai de trois ans à compter de l'acceptation dudit article par le peuple et les cantons. $2 \mathrm{Si}$ les lois d'application afférentes ne sont pas entrées en vigueur dans les trois ans à compter de l'acceptation de l'art 121a par le peuple et les cantons, le Conseil fédéral édicte provisoirement les dispositions d'application nécessaires par voie d'ordonnance'.
}

${ }_{53}$ Article 25 paragraphs 3 and 4 FMPA. 
extension of the freedom of movement to Croatia was negotiated in a new protocol, which was initialled in 2013. The protocol envisages the full free movement of persons, with Croatia following a ten-year transitional regime. However, the new constitutional provisions exclude the conclusion of new agreements that are not compatible with the introduction of quotas for immigrants. The Federal Council has concluded that it is not in a position to sign the protocol to extend the freedom of movement to Croatia in its original version. The admission of Croatian nationals to Switzerland is still subject to the provisions of the Foreign Nationals Act (FNA). ${ }^{54}$ However, from 1 July 2014, Croatian nationals are subject to separate quotas (outside those for third-country nationals) on access to the Swiss labour market. ${ }^{55}$ Yet, after the Bern decisions regarding Croatia, the European Commission decided to suspend negotiations on Switzerland's participation in the European research programme Horizon 2020 and the Erasmus student exchange programme. ${ }^{56}$

On 20 June 2014, the Federal Council presented a plan for implementing a new article of the Swiss Constitution concerning immigration. ${ }^{57}$ The new model of receiving nationals of other countries in Switzerland envisages setting quantitative limits and quotas. For such purposes, different economic and labour market indicators will be taken into account such as the labour shortage rate or unemployment rate. The implementation of Article 121a of the Constitution of the Swiss Confederation has been defined as a shared task of the Confederation and the cantons. Consequently, the Federal Council plans to consult a body established on an ad-hoc basis which brings together federal and cantonal representatives dealing with migration and the labour market, as well as social partners.

And so it remains a central issue how the new Swiss immigration system which complies with the spirit of Article 121a of the Constitution of the Swiss Confederation can be reconciled with the foreign policy conducted by the Federal Council, the aim of which is to maintain and renew

\footnotetext{
54 Federal Act on Foreign Nationals (Foreign Nationals Act, FNA) of 16 December 2005, 142.20 .

55 According to Federal Department of Justice and Police (FDJP) and the Federal Office for Migration (FOM) the quotas for Croatian nationals comprise 50 one-year B permits and 450 short-term L permits < https://www.bfm.admin.ch//content/dam/data/migration/ schweiz_-_eu/personenfreizuegigkeit/factsheets/fs-hr-e.pdf> accessed 10 June 2014.

56 Commission, 'Developments following the Swiss referendum on 9 February - statement by European Commissioner László Andor on behalf of the European Commission to European Parliament plenary session, Strasbourg, 26 February 2014; Quirin Schiermeier, 'EUSwiss Research on Shaky Ground' (2014) 506 Nature (20 February 2014) 277.

57 Département fédéral de justice et police DFJP, Département fédéral des affaires étrangères DFAE, Département fédéral de l'économie, de la formation et de la recherche DEFR 'Art 121a Cst (Gestion de l'immigration). Plan de mise en oeuvre' <http://www.ejpd.admin. $\mathrm{ch} / \mathrm{dam} / \mathrm{data} / \mathrm{bfm} / \mathrm{eu} / \mathrm{fza} /$ personenfreizuegigkeit/umsetz-mei/konzept-umsetz-f.pdf $>$ accessed 15 September 2014.
} 
the relations with the EU by means of bilateral agreements. At the Joint Committee meeting held on 12 June 2014, Switzerland requested to revise the FMPA in accordance with its Article 18. The formal request in that regard was made on 4 July 2014 by the Swiss Federal Office for Migration. ${ }^{58}$ The seriousness of the matter is indicated by the fact that a reply came from the High Representative and Vice-President of the European Commission (Catherine Ashton) directly to the President of the Swiss Confederation (HE Didier Burkhalter). It was a negative reply, where the High Representative indicated that the changes suggested by Switzerland concerning the introduction of 'quantitative limits and quotas combined with a preference for Swiss nationals would be in fundamental contradiction to the objective of the Agreement on the free movement of persons'. ${ }^{59}$

\section{Conclusion}

The barriers in the exercise of the freedom to provide services on a temporary and continuous basis between the EU and Switzerland are part of a wider context where it is necessary to modernise the system of EU-Swiss bilateral agreements. Already in 2010, the Council pointed out in its conclusions that 'while the present system of bilateral agreements has worked well in the past, the challenge of the coming years will be to go beyond this complex system, which is creating legal uncertainty and has become unwieldy to manage and has clearly reached its limits' and indicated an urgent case for 'the dynamic adaptation of agreements to the evolving acquis' ${ }^{60}$ The need to change relations between the Union and Switzerland also results from the obligation upon Swiss authorities to introduce into Swiss law an act which implements the outcome of the referendum 'against mass immigration'.

The ongoing negotiations currently concern the reform of the institutional framework in which Swiss-EU bilateral agreements function. ${ }^{61}$ The

\footnotetext{
58 Swiss Federal Office for Migration <http://www.europa.admin.ch/index.html?lang=fr> accessed 10 September 2014.

59 Letter from Catherine Ashton to HE Didier Burkhalter (24 July 2014) <https:// www.bfm.admin.ch/content/dam/data/bfm/eu/fza/personenfreizuegigkeit/umsetzmei/20140725-schreiben-ashton.pdf> accessed 10 September 2014.

60 Council Conclusions, December 2010, <http://www.consilium.europa.eu/uedocs/cms data/docs/pressdata/EN/foraff/118458.pdf> accessed 10 June 2014.

${ }_{61}$ Conseil de l'Union européenne, Mandat de négociations pour un accord UE - Suisse sur un cadre institutionnel, Bruxelles, le 6 mai 2014, 9525/14 PRESSE 267 <http://www. consilium.europa.eu/uedocs/cms_data/docs/pressdata/fr/er/142504.pdf > accessed 2 October 2014; Council Decision authorising the opening of negotiations on an agreement between the European Union and the Swiss Confederation on an institutional framework governing bilateral relations <http://www.sonntagszeitung.ch/pdf/EU-Mandat.PDF> accessed 2 October 2014; Conseil federal, Mandat de négociation avec l'Union européenne dans le domaine institutionnel, Berne <http://www.admin.ch/aktuell/00089/?lang=fr\&msgid=51490> accessed 18 December 2013.
} 
negotiating mandate granted to the European Commission by the Council $^{62}$ assumes that a mechanism will be established to execute supervision and legal control of how Switzerland applies such agreements. This is supposed to ensure the uniform application and interpretation of the EU acquis. Pursuant to the negotiating directives, the European Commission should become the body in charge of the supervision of the execution of the bilateral accords while disputes between the parties to such agreements should be settled by the CJEU, with its rulings to be legally binding for the EU and Switzerland. Also, the institutional framework is to commit the parties to dynamically adjust agreements with Switzerland to the EU acquis. However, such solutions seem difficult to accept for Switzerland as they violate the autonomy of the Confederation. Besides, Switzerland shows a willingness to adopt EU legislation only in areas it selects itself. This is why another possible solution, that is, replacing around a hundred and twenty bilateral agreements between the EU and Switzerland with a framework agreement providing for a clearer institutional mechanism facilitating the adaptation of Swiss law to secondary EU law, for example one which operates as part of the EEA, ${ }^{63}$ also seems hardly acceptable to the Swiss. Another solution would be the conclusion of an association agreement between the EU and Switzerland. The basis for such talks could be the accords negotiated recently with Moldova and Georgia. ${ }^{64}$ Still, the final form of EU-Swiss relations depends on how flexible the EU is likely to be and which concessions it will be ready to offer Switzerland which is keen to deepen integration only on its own conditions and in selected areas.

\footnotetext{
62 Une décision du Conseil du 6 mai 2014 autorisant l'ouverture de négociations relatives à un accord entre l'UE et la Suisse sur un cadre institutionnel régissant les relations bilatérales.

63 Alfred Tovias, 'Exploring the 'Pros' and 'Cons' of Swiss and Norwegian Models of Relations with the European Union' (2006) 41(2) Cooperation \& Conflict 203. Article 102 (1) of the Agreement on the European Economic Area [1994] OJ L1/3 states that in order to guarantee the legal security and the homogeneity of the EEA, the EEA Joint Committee shall take a decision concerning an amendment of an Annex to this Agreement as closely as possible to the adoption by the Community of the corresponding new Community legislation with a view to permitting a simultaneous application of the latter as well as of the amendments of the Annexes to the Agreement. To this end, the Community shall, whenever adopting a legislative act on an issue which is governed by this Agreement, as soon as possible inform the other Contracting Parties in the EEA Joint Committee'.

64 Adam Lazowski, 'The End of Chocolate Box-style Integration? EU-Swiss Relations after the Referendum' (CEPS Commentary, 28 February 2014) 4; Association Agreement between the European Union and the European Atomic Energy Community and their Member States, of the one part, and the Republic of Moldova, of the other part [2014] OJ L260/4; Association Agreement between the European Union and the European Atomic Energy Community and their Member States, of the one part, and Georgia, of the other part [2014] OJ L261/4.
} 
